\title{
Synergism/complementarity of recombinant adenoviral vectors and other vaccination platforms during induction of protective immunity against malaria
}

\author{
Ana Paula Morais Martins Almeida, Oscar Bruna-Romero/ ${ }^{+}$ \\ Departamento de Microbiologia, Universidade Federal de Minas Gerais, Belo Horizonte, MG, Brasil
}

\begin{abstract}
The lack of immunogenicity of most malaria antigens and the complex immune responses required for achieving protective immunity against this infectious disease have traditionally hampered the development of an efficient human malaria vaccine. The current boom in development of recombinant viral vectors and their use in prime-boost protocols that result in enhanced immune outcomes have increased the number of malaria vaccine candidates that access pre-clinical and clinical trials. In the frontline, adenoviruses and poxviruses seem to be giving the best immunization results in experimental animals and their mutual combination, or their combination with recombinant proteins (formulated in adjuvants and given in sequence or being given as protein/virus admixtures), has been shown to reach unprecedented levels of anti-malaria immunity that predictably will be somehow reproduced in the human setting. However, all this optimism was previously seen in the malaria vaccine development field without many real applicable results to date. We describe here the current state-of-the-art in the field of recombinant adenovirus research for malaria vaccine development, in particular referring to their use in combination with other immunogens in heterologous prime-boost protocols, while trying to simultaneously show our contributions and point of view on this subject.
\end{abstract}

Key words: malaria vaccines - Plasmodium vivax - Plasmodium falciparum - Adenoviridae - immunization schedule

Plasmodium falciparum and Plasmodium vivax cause the vast majority of cases of human malaria worldwide. In mice, Plasmodium yoelii, Plasmodium chabaudi and Plasmodium berghei serve as models for studying different aspects of the human disease - i.e. immunology, pathology or drug/vaccine development although infection, as well as proteins/antigens generated by these parasites, only partially resembles those of the human species. Even though malaria infection can be treated with drugs, selection of resistant strains and emergence of parasites that can cause severe pathologies are being increasingly documented (Baird 2009, Mita et al. 2009). Enormous efforts are being made to develop a protective anti-malaria vaccine, which will reduce the costs of treatment as well as the social impacts for the regions affected.

A commercial malaria vaccine must be feasible, since it has been repeatedly demonstrated that irradiated sporozoites completely protect hosts against the disease (Nussenzweig et al. 1967, Clyde 1990), and antibody transfers from hyperimmune individuals to naivve subjects are also able to eliminate malaria parasites (McGregor 1964, Clyde 1975). However, the use of irradiated sporozoites for mass vaccination is not strategically achievable and the malaria vaccine that is closer

Financial support: INCTV/CNPq

+ Corresponding author: oscar@ufmg.br

Received 1 April 2011

Accepted 15 June 2011 to be translated into a commercial human vaccine, i.e. Glaxo Smithkline's RTS,S/AS01E (Olotu et al. 2011), will probably protect only partially against $P$. falciparum and nothing against $P$. vivax.

One of the major obstacles for the development of a vaccine against malaria has traditionally been the lack of immunogenicity of the candidate formulations. As an example, researchers believe that protection in RTS,S-vaccinated children is higher when antibody titres against the circumsporozoite protein (CSP) - the plasmodial component of the vaccine - are above 18-40 $\mathrm{EU} / \mathrm{mL}$ (depending on the analysis model), but neither RTS,S/AS01E nor other RTS,S formulations, are still capable of inducing those titres in all vaccinated kids (Olotu et al. 2011). Amongst the different recombinant vaccine platforms tested during the last decades to address this deficit, viral vectors (Rocha et al. 2004, Li et al. 2007, Limbach \& Richie 2009, Hill et al. 2010) represent a significant move forward, for its capacity to improve the potency, functionality and duration of immune responses to refractory vaccine targets, such as CSP, which require complex responses to induce protection.

Adenoviruses currently stand as an unavoidable option among the different viruses already tested as vectors for experimental malaria vaccine after repeated demonstrations of their high immunogenicity and capacity of inducing potent T-cell - and to a lesser extent also B-cell - memory immune responses against transgenic products without causing significant pathology (Peiperl et al. 2010). Here, we review the most effective of the use of different adenoviruses vectors along with other vaccine platforms to induce the complex immune responses required to neutralize/eliminate the pre-erythrocytic and asexual erythrocytic stages of the Plasmodium parasite (Table I). 
Adenoviruses in malaria vaccine development - Most of current's investment in malaria vaccine development is still being made for the development of a $P$. falciparum vaccine because this parasite is responsible for most fatal cases of the disease, especially in young children in Africa. However, a $P$. vivax vaccine is also required because vivax malaria is spread worldwide and is gradually becoming more harmful, being responsible for an increasing number of cases of severe and even fatal malaria (Kochar et al. 2005, Tjitra et al. 2008). In both cases, antigens chosen to induce protective immunity in the host must belong to the pre-erythrocytic or the asexual erythrocytic stages of the parasite's life cycle (see the complete cycle somewhere else in this journal issue).

Recombinant adenoviruses as vaccine candidates against the pre-erythrocytic stages of malaria - Preventing sporozoites to invade liver cells and/or eliminating infected hepatocytes results in no clinical symptoms of malaria and for $P$. vivax in no remaining dormant parasites (hypnozoites) that can cause relapses. However, the effector mechanisms underlying protection against Plasmodium pre-erythrocytic stages are complex and clear correlates of immunity are still needed. In addition to components of the innate immune system, such as gamma-delta T-cells, natural killer cells and natural killer T-cells, multifactorial adaptive mechanisms including antibodies, $\mathrm{CD}^{+}$and $\mathrm{CD} 4^{+} \mathrm{T}$-cells, as well as interferon gamma (IFN $\gamma$ ) have been demonstrated to be key in protection against Plasmodium infection (Doolan \& Martinez-Alier 2006, Schwenk \& Richie 2011). Nonetheless, the need of inducing strong parasite-specific $\mathrm{CD} 8^{+} \mathrm{T}$-cells responses and IFN $\gamma$ against the pre-erythrocytic forms of Plasmodium seems to be the only prevalent consensus (Ferreira et al. 1986, Schofield et al. 1987). Luckily, these are the most significant traits that result from immunization with most viral vectors and in particular with recombinant adenoviruses (Tatsis et al. 2007) and poxviruses (Harrington et al. 2002). This is because, by nature, most viruses have evolved to be intracellular parasites, and hosts must induce IFN $\gamma$ and specific $\mathrm{CD}^{+}{ }^{+} \mathrm{T}$-cell responses to promote major histocompatibility complex class I recognition and elimination of infected cells. In the process, not only viral antigens but also heterologous proteins are presented to the immune system, resulting in an outcome that is beneficial to protect against malaria.

As previously mentioned, the pre-erythrocytic stage antigen CSP was the first antigen to be vectorized in viruses for immunization. Most viral vectors developed to date have included its recombinant sequence (either complete or the most significant $\mathrm{T}$ or B-cell epitopes) in their genomes. Influenza viruses, poxviruses [vaccinia, NYVAC, ALVAC and vaccinia modified ankara virus strain recombinant vector (MVA)], human (HAd) and chimpanzee (AdC) adenoviruses, and others, have documented successful immunization and development of protective CSP-specific $\mathrm{CD} 8^{+} \mathrm{T}$-cells responses and IFN $\gamma$ production. Moreover, the immunological relevance of this antigen is such that even for the first prime-boost immunization protocol ever described ( $\mathrm{Li}$ et al. 1993), which used influenza and vaccine recombinants, CSP was chosen as model.
In the case of recombinant adenoviral vectors, HAd serotype 5 (HAd5V) was initially chosen as the prototype for immunization purposes. The first experimental evidence that HAd5V could be efficiently used as a vector for malaria vaccination was obtained during a study performed by Rodrigues et al. (1997), in which the immunodominant CSP antigen of the P. yoelii sporozoite was expressed in a replication-defective HAd5V vector (Rodrigues et al. 1997). A single immunization with the adenoviral vector elicited unprecedented simultaneous high levels of both cellular and humoral responses against CSP and, in $40 \%$ of the mice, complete protection against $P$. yoelii infection.

These encouraging results obtained in animals with the use of HAd5V as vaccine vector - not only for malaria but also for several other diseases - were dampened down when researchers recently suggested that, in humans, the high prevalence of neutralizing antibodies worldwide could neutralize the vector and block vaccination (Pichla-Gollon et al. 2009). In contrast, and despite the initial frustrating outcome reporting lack of protection against human immunodeficiency virus (HIV) infection, Merck's STEP trial showed something very relevant: $75 \%$ of human beings were immunized by the three-dose HAd5V-vectored vaccination protocol, irrespectively of their anti-adenovirus immune status before the beginning of the trial (Buchbinder et al. 2008). Since there is no final conclusion on the actual relevance of pre-existing immunity, HAd5V is still in use as a vector, but different strategies are simultaneously being developed to circumvent any possible negative effects that may show up. These include: (i) changing the adenoviral strain to other less frequent human or monkey serotypes (ii) using chimeric capsid-modified adenoviruses or (iii) including the HAd5V vector into heterologous prime-boost protocols that require a maximum of one dose of this vector in combination with others (poxviruses, proteins in different adjuvants etc.). The latter is the alternative supported by our group because does not represent a change in the traits of the immunization vector, while all other options result in changes of the type of target cells infected or in the capacities of the vectors to modulate the immune system, something that has already been demonstrated to change the immunogenic profile of the vaccine candidate (Ophorst et al. 2004, Adams et al. 2011).

Regarding the use of the first strategy to avoid preexisting immunity, researchers at the Dutch company Crucell (Vogels et al. 2003, Ophorst et al. 2004, 2006, Shott et al. 2008) have focused in the use of HAd35V alone or in prime-boost combination with HAd5V, both expressing CSP, and showed that, when combined in a prime-boost protocol, these recombinants adenoviruses induced high CSP-specific cellular and humoral immune responses and, in mice, significantly inhibited liver infection upon a high-dose sporozoite challenge. Moreover, in collaboration with other groups, HAd35V was also tested as vaccine vector to improve immune responses induced by RTS,S/AS01B, a protein-in-adjuvant vaccine. In this study, priming with HAd35V expressing a truncated form of $P$. falciparum CSP, followed by 
two RTS,S/AS01B boosters, resulted in IFN $\gamma$ T-cell responses in a Rhesus monkey model that were significantly increased in both magnitude and duration and kept antibody levels above those induced with three doses of RTS,S/AS01B or with two doses of HAd35V expressing CSP (Stewart et al. 2007). Also at Crucell, Radosevic et al. (2010) are focusing in the use of prime-boost protocols that include HAd26V in combination with HAd35V, HAd5V and/or protein-in-adjuvant formulations, showing in mice and monkeys that some of these combinations induce significant Th1 immune responses against $P$. falciparum CSP (yeast recombinant) and liver stage antigen 1 (Rodriguez et al. 2009, Radosevic et al. 2010). Future pre-clinical and clinical trials should demonstrate the relative potency of each vector and suggest the final vaccination protocol to be used for vaccination of human beings, but as they own acknowledge, HAd5V should be considered a valid option because of its superior immunogenicity and the fact that only a very small percentage of children under two years (the main target population of a malaria vaccine) carry anti-HAd5V antibodies.

Crucell researchers have also tried to develop chimeric viruses (2nd strategy to avoid pre-existing immunity) not for malaria but for HIV infections. In this field, and in collaboration with the group of Dr Daniel Barouch (Nanda et al. 2005), they tested a chimeric HAd35V vector containing HAd5V fibre knobs. This vector displayed immune properties different from the parental serotypes, with a receptor usage and immunogenicity profile similar to that of HAd5V, consequently being more immunogenic than HAd35V. They also reported (Roberts et al. 2006) the use of a second chimeric vector for HIV

TABLE

Major published reports on Plasmodium antigens encoded by adenoviral vectors used as experimental malaria vaccines

\begin{tabular}{|c|c|c|c|c|}
\hline Antigen & Antigen delivery & Animal model & Outcome of vaccination & Reference \\
\hline$P y \mathrm{CSP}$ & HAd5V & Mice & $\begin{array}{l}\text { Forty percent of the mice were } \\
\text { sterile protected against } \\
\text { Plasmodium yoelii infection. }\end{array}$ & Rodrigues et al. (1997) \\
\hline$P y \mathrm{CSP}$ & HAd5V + Vac & Mice & $\begin{array}{l}\text { One hundred percent } \\
\text { of mice sterile were protected } \\
\text { against } P \text {. yoelii infection. }\end{array}$ & Bruna-Romero et al. (2001) \\
\hline$P y \mathrm{CSP}$ & HAd35V + HAd5V & Mice & $\begin{array}{c}\text { Potent } \mathrm{Ab} \text { and } \mathrm{CD} 8^{+} \mathrm{T} \text { cell responses; } \\
92-94 \% \text { reduction in liver } \\
\text { infection (parasite load by } \mathrm{PCR}) \\
\text { upon } P . \text { yoelii sporozoite challenge. }\end{array}$ & Ophorst et al. (2006) \\
\hline$P y \mathrm{CSP}$ & HAd35V + RTS,S/AS01B & Rhesus monkeys & High levels of specific IFN $\gamma \mathrm{T}$ cells. & Stewart et al. (2007) \\
\hline$P y \mathrm{CSP}$ & HAd $35 \mathrm{~V}+\mathrm{HAd} 26 \mathrm{~V}+$ protein & Mice & Robust Th1-type immune response. & Radosevic et al. (2010) \\
\hline$P y \mathrm{CSP}$ & Capsid-modified HAd5V & Mice & High levels of $\mathrm{Ab}$ and $50 \%$ protection. & Shiratsuchi et al. (2010) \\
\hline PfMe-TRAP & HAd5V, AdCs and MVA & Mice & $\begin{array}{l}\text { High levels of } \mathrm{Ab} \text { and } \mathrm{T} \text { cells, } \\
\text { specially when using AdC } 63 \\
\text { or AdC } 9 \text { plus MVA boost. }\end{array}$ & Reyes-Sandoval et al. (2010) \\
\hline PfMe-TRAP & AdC63V + MVA & Rhesus monkeys & $\begin{array}{l}\text { Outstanding } \mathrm{Ab} \text { and } \mathrm{T} \text { cell responses; } \\
\text { long-lasting } \mathrm{T} \text { cell memory. }\end{array}$ & Capone et al. (2010) \\
\hline PfAMA-1 & AdC63V, MVA and protein & Rhesus monkeys & $\begin{array}{l}\text { Outstanding } \mathrm{Ab} \text { and/or T-cell } \\
\text { responses depending on } \\
\text { tailored protocols } \\
\text { (different vector combinations). }\end{array}$ & Draper et al. (2010) \\
\hline PfMSP-1 & HAd5V, AdC and MVA & Mice & $\begin{array}{l}\text { Potent cellular immune responses; } \\
\text { Ab titres similar to those obtained } \\
\text { by three immunizations with } \\
\text { protein in Freund's adjuvant. }\end{array}$ & Goodman et al. (2010) \\
\hline Pf MSP-1 & AdC, MVA and protein & Mice & $\begin{array}{l}\text { Outstanding } \mathrm{Ab} \text { and } \mathrm{T} \text { cell response } \\
\text { (but depending on the vector } \\
\text { combination used). }\end{array}$ & Douglas et al. (2010) \\
\hline
\end{tabular}

Ab: antibodies; AdC: chimpanzee adenovirus vector serotype; HAd: human adenovirus vector serotype; IFN $\gamma$ : interferon gamma; MVA: vaccinia modified ankara virus strain recombinant vector; PfAMA-1: Plasmodium falciparum apical membrane antigen 1; PfME-TRAP: P. falciparum multiepitope string (Oxford University design) fused to thrombospondin-related anonymous protein; PfMSP-1: P. falciparum merozoite surface protein 1; PCR: polymerase chain reaction; PyCSP: $P$. yoelii circumsporozoite protein; Vac: vaccinia virus; RTS,S/AS01B: commercial human vaccine (Glaxo Smithkline). 
immunization, based on the HAd5V serotype but with hexon hypervariable regions belonging to the HAd48V serotype. This vector induced in mice cellular immune responses against HIV gag protein comparable to those induced by HAd5V vector without significant neutralization by pre-existing immunity. However, none of these vectors were yet reported as malaria vaccine candidates yet, so we cannot evaluate their properties at this time.

Working in malaria vaccine development, Shiratsuchi et al. (2010) constructed a novel HAd5V recombinant that displayed the main B-cell epitope of $P$. yoelii CSP within the adenovirus hexon and/or fibre, while expressing the full-length $P$. yoelii CSP within infected cells, aiming at the simultaneous induction of potent B-cell and T-cell responses. Viruses with the hexon hypervariable region 1 replaced with the CSP B epitope induced not only the highest humoral response but also significant protection against a subsequent malaria challenge and, most importantly, circumvented neutralization by pre-existing anti-HAd5V antibodies.

For malaria prevention also, Palma et al. (2011) constructed a recombinant HAd5V expressing two different B cell epitopes of $P$. falciparum CSP within the hexon protein. Different from all others studies cited here, these two recombinant vectors were replicative. Results show that CSP epitopes displayed on adenoviruses particles could elicit neutralizing antibodies, even when tested in mice, animals in which adenoviruses neither replicated nor expressed late proteins (including hexon).

The third strategy mentioned above, hence, the use of heterologous prime-boost protocols that involve administration of a single dose of HAd5V recombinants, has been our choice for the development of an anti-malaria vaccine. In the case of Plasmodium pre-erythrocytic antigens, and based in previous works from Dr Ruth and Victor Nussenzweig's laboratories at New York University ( $\mathrm{Li}$ et al. 1993) that resulted in the description of the first prime-boost immunization protocols, we showed a decade ago (Bruna-Romero et al. 2001) that immune responses generated by the CSP-recombinant HAd5V vector could be further improved by the sequential administration of a poxviral recombinant vector (VacPyCS), a western reserve vaccinia virus recombinant expressing the same antigen, as a booster. This heterologous prime/ boost protocol was able to protect $100 \%$ of experimental animals against murine malaria after a challenge with live $P$. yoelii sporozoites.

Currently, our experiments with $P$. vivax antigens are being designed to even further increase the immunogenicity of CSP. For this, CSP has been included within the hepatitis $\mathrm{B}$ virus core antigen ( $\mathrm{HBcAg}$ ) to form a virallike particle or, alternatively, fused to the herpes simplex virus I (HSV-1) glycoprotein D carrier protein (gD). Both chimeras are being administered either in their purified forms or expressed in loco by means of recombinant adenoviruses. The HBcAg spontaneously assembles into virus-like particle composed of 180-240 monomers, that are highly immunogenic for B-cell epitopes inserted into the immunodominant loop region located at the tip of the surface "spikes" on particles mounted with $\mathrm{HBcAg}$, as well as for the T-cell epitopes placed at the C-terminus of the same molecule (Francis et al. 1990, Bottcher et al.
1997, Birkett et al. 2002). HSV-1 gD binds to the herpes virus entry mediator and stimulates antigen presentation by dendritic cells and inhibition of Tregs (Murphy et al. 2006, DiMenna et al. 2010). Based on our current results, it is our hypothesis that these recombinant imunogens, i.e. the chimeric $\mathrm{HBcAg}$ and $\mathrm{gD}$ pure proteins, given alone or in combination with adenoviruses that are able to express them in infected host cells, will generate simultaneous, potent and long-lasting CSP-specific cellular and humoral immune responses (hypothesis explained in Fig. 1).

Another antigen that has also been used in vaccine formulations against the pre-erythrocytic stages of Plasmodium is the thrombospondin-related anonymous protein (TRAP)/sporozoite surface protein 2. The group of Dr Adrian Hill and colleagues at Oxford University have been using this antigen in a proprietary design, known as the multiepitope (ME)-TRAP (Moorthy et al. 2003) a transgene that contains P. falciparum TRAP fused in frame to a $\mathrm{ME}$ string of $\mathrm{B}, \mathrm{CD}^{+}$and $\mathrm{CD} 8^{+}$ epitopes from CSP and others. This antigen was initially used as a DNA vaccine, further complemented by the addition of a poxviral MVA vector to boost responses. More recently, adenoviral vectors AdC63 and AdC9 have also been included in the immunization routines (Capone et al. 2010, Reyes-Sandoval et al. 2010) and authors claim that, by using these recombinant virus combinations, they efficiently induce potent Th1 polyfunctional protective $\mathrm{T}$ cells.

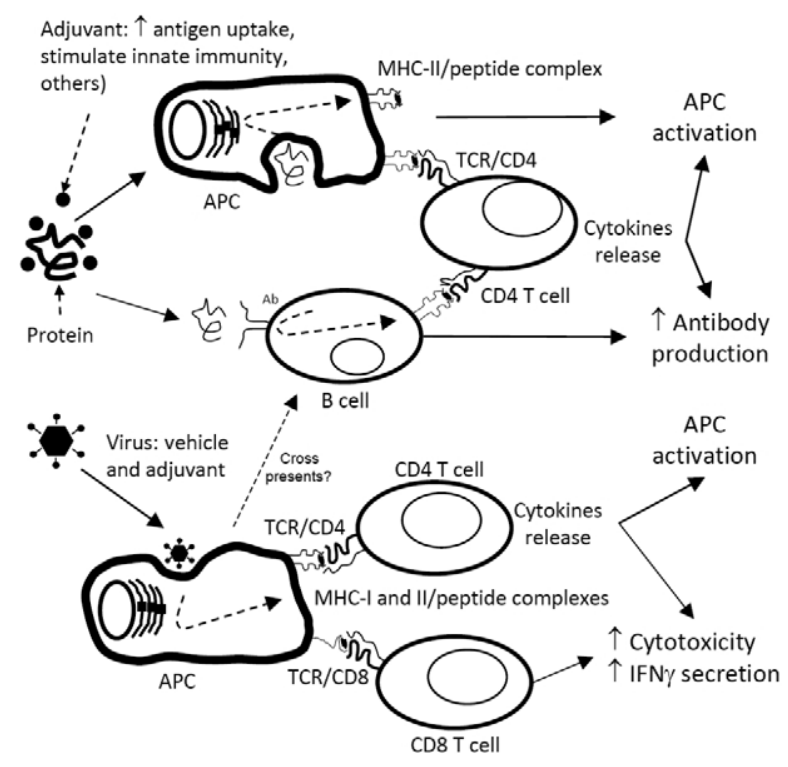

Fig. 1: summary of events related to major acquired immunity antigen processing and presentation mechanisms that take place after administration of a protein-in-adjuvant vaccine or a recombinant viral vaccination vector. As can be observed, the major mechanisms induced by each immunogen can be either complementary and/or synergistic. The ratio of complementarity/synergy may be different for each viral vector and vaccination adjuvant considered, depending on the immune traits associated with those immunogens. Ab: antibody; APC: antigen-presenting cell; IFN $\gamma$ : interferon gamma; MHC: major histocompatibility complex; TCR: T-cell receptor. 
Recombinant adenoviruses as vaccine candidates against the erythrocytic stages of malaria - In principle, since human leukocyte antigen class I or II molecules are absent from the surface of the parasite or the infected red blood cell, the focus in an asexual blood-stage malaria vaccine is the induction of antibodies against intra-erythrocytic and free blood forms of Plasmodium (Fowkes et al. 2010). These antibodies should neutralize free merozoites, stop further infection of red blood cells and bring to an end subsequent multiplication of the parasite. This type of vaccines may not be sterilizing, but greatly reduce/eliminate symptoms and pathology. This simplistic view is, however, much more complex when the detailed immune mechanisms involved are studied. Thus, to induce potent and efficient antibody responses and memory B-cells, T-cell help and cytokine production are still required and some authors (McCall \& Sauerwein 2010) have described a direct relation between protection and specific T-cell induction against bloodstage parasite antigens. Thus, at the end of the road, vaccination must not only focus on antibodies but also on generation of specific T-cells.

The main blood-stage candidates currently in study for development of a recombinant adenoviral vaccine against Plasmodium are: apical membrane antigen 1 (AMA-1), merozoite surface protein 1 (MSP-1) and Duffy-binding protein (DBP), the latest being of particularly importance to prevent $P$. vivax infection.

AMA-1 is a type I integral membrane protein found in all species of Plasmodium. This protein is frequently described as a blood-stage malaria vaccine candidate, but some studies suggest that AMA-1 has a dual role during Plasmodium infection, acting both in the pre-erythrocytic (Silvie et al. 2004) and erythrocytic (Triglia et al. 2000) stages, and antibodies against AMA-1 have been demonstrated to block sporozoite invasion of the hepatocytes and also prevent merozoite invasion of red blood cells.

In animal models, antibodies directed against AMA-1 induce protection against Plasmodium challenges, but clinical trials using AMA-1 protein administered in different adjuvants showed limited immunogenicity in humans (Saul et al. 2005, Hu et al. 2008, Malkin et al. 2008, Roestenberg et al. 2008, Pierce et al. 2010). To improve the immunogenicity of AMA-1 and strongly enhance the cellular immune responses that could stop the development of both pre-erythrocytic as well as erythrocytic forms, recombinant viral vectors are being used together or as an alternative to protein-based vaccines (Draper et al. 2010).

MSP-1 is synthesized from the onset of schizogony as a $195 \mathrm{kDa}$ precursor that undergoes a series of proteolytic cleavages during invasion of host erythrocytes. After the first proteolytic cleavage only a fragment of $42 \mathrm{kDa}$ $\left(\mathrm{MSP}^{-}{ }_{42}\right)$ remains attached to the membrane. This fragment is then cleaved again generating two others, MSP$1_{33}$ (soluble) and MSP-1 $1_{19}$ (glycosylphosphatidylinisotolanchored) (Kadekoppala \& Holder 2010). MSP-1 $1_{42}$ and MSP- $_{19}$ are leading vaccine candidates since there is evidence of protection mediated by antibodies against these molecules (John et al. 2004, Stanisic et al. 2009). However, to date, when tested as proteins-in-adjuvants in combination with different immune stimulants, they did not protect immunized humans (Malkin et al. 2007, Ogutu et al. 2009).

DBP is a $140 \mathrm{kDa}$ protein that serves as a $P$. vivax ligand for a chemokine receptor present on the surface of the erythocytes, the Duffy antigen/receptor for chemokines, also known as the Duffy blood group. Since $P$. vivax is highly dependent on interaction with the Duffy blood group to invade human erythrocytes, Duffy-negative humans are mostly (although it has been shown that not in all cases) resistant to invasion by $P$. vivax and antibodies against this molecule can prevent attachment and/or invasion of erythrocytes (Miller 1976). Antibodies against DBP have been associated with protection in humans (King et al. 2008) and in vaccinated animals inhibited erythrocyte adherence in vitro (Michon et al. 2000).

Regarding the development of adenoviral vaccine candidates encoding these three antigens, several reports have been published recently. Bruder et al. (2010) tested in rabbits the impact of glycosylation and cellular localization of $P$. falciparum AMA-1 and $\mathrm{MSP}_{42} \mathrm{1}_{42}$ expressed by recombinant HAd5V vectors on the immune responses detected after immunization. Their results show that when secreted to the cell surface, both antigens induce significantly higher levels of antibodies and $\mathrm{T}$ cells against both antigens and that glycosylation does not interfere with functionality. In this study, humoral immune responses induced by the HAd5V adenovectors elicited $99 \%$ and $60 \%$ inhibition of parasite growth, respectively for each antigen.

To achieve broad, polyfunctional and potent immune responses in animal models Draper et al. (2010) used AdC63 and MVA, both expressing P. falciparum AMA-1, and also AMA-1 protein/virus admixtures for heterologous prime-boost immunizations of Rhesus monkeys. Authors show that sequential immunization with adeno and poxviral vectors induce strong and long-lasting, polyfunctional [tumor necrosis factor alpha (TNF $\alpha$ ), IFN $\gamma$ and interleukin (IL)2-secreting] $\mathrm{CD}^{+}$and $\mathrm{CD}^{+} \mathrm{T}$-cell responses that exhibit a central memory-like phenotype. Immunizations with AdC63-MVA-protein or AdC63-protein-protein regimens, regardless of the adjuvant used, induced B-cells and high titre functional IgG responses that inhibited the growth of $P$. falciparum in vitro. The authors did not test, however, the possibility of a first dose of protein-in-adjuvant followed by an adenoviral vector booster dose, which in our hands has been the most efficient immunization protocol amongst all studied to date, not only for $P$. vivax AMA-1, but also for the other two blood-stage antigens we routinely use for immunization, i.e. MSP-1 and DBP.

Goodman et al. (2010) studied the immunogenicity of two allelic forms of $P$. falciparum MSP- $1_{42}$ when administered as a HAd5V, distinct serotypes of AdC or as a recombinant MVA vector. Authors suggest that replacing HAd5V with simian adenoviral vector compromised neither antibody nor $\mathrm{T}$ cell responses in mice, leading to antibody titres similar to those obtained by three immunizations with protein in Freund's adjuvant. Further comparisons in other animal models and in clinical trials are expected, which will help to validate these results. 
In a similar work, comparing immunization protocols based in AdC, MVA and protein in adjuvant, Douglas et al. (2010) highlighted the importance of testing tailored protocols to obtain the immune responses pretended. They showed that protocols containing AdC63 and MVA induced maximal $\mathrm{CD} 8^{+} \mathrm{T}$ cell responses while maximal $\mathrm{IgG}$ responses were elicited by protocols containing AdC63 and protein. They also showed the feasibility of using an admixture of the viral vectors with proteins in order to simplify the immunization regiments, since two-shot immunizations with admixed antigens elicited similar responses than three-shot immunizations.

All reports regarding recombinant adenoviruses mentioned up to here have used P. falciparum antigens. Our research group is however very interested in developing a vaccine against $P$. vivax. We have pursued the idea that a heterologous prime-boost immunization regime that includes administration of an antigen as an adequate protein-in-adjuvant (Montanide ISA720 preferred) formulation, followed by the administration of an adenovirus vector, could be one of the best approaches to achieve longer-lasting simultaneous B and T immune responses against $P$. vivax. Immune traits of each of these two immunogens when given separately or in combination are depicted in Figs 1 and 2 and led us to propose this hypothesis. In a proof of concept of this methodology we
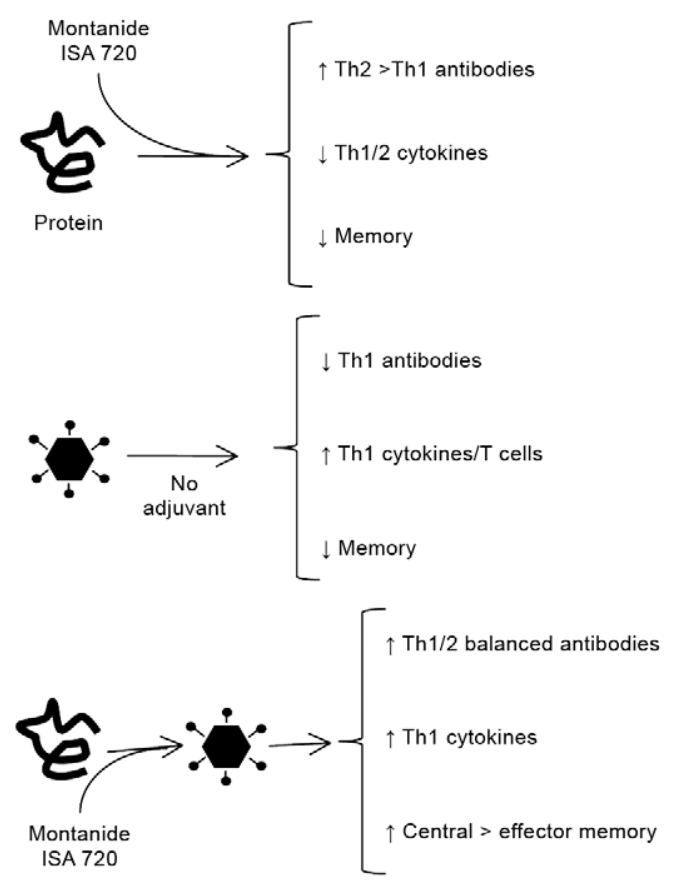

Fig. 2: major immune outcomes observed (unpublished observations) after administration to experimental animals (mice) of four recombinant Plasmodium vivax proteins-in-adjuvant Montanide ISA 720 (Seppic Air Liquide, France) or recombinant human type 5 adenoviruses, individually or sequentially administered according to heterologous prime-boost immunization protocols. Complementarity was intended more than synergy because the immune responses elicited with this vaccination protocol should be broad, as required against antigens of the pre-erythrocytic as well as the erythrocytic stages of $P$. vivax. are using the three main blood-stage antigens described here. Thus, we have expressed in Escherichia coli and in eukaryotic cells (by means of 3 independent recombinant HAd5 viruses) the extracellular domains of AMA-1 (Rodrigues et al. 2005), a chimeric form of MSP- $1_{19}$, named MSP-1 $1_{19}$-PADRE, in which the universal T PanAllelic DR epitope is fused to the C-terminus of $P$. vivax MSP- $_{19}$ sequence (Cunha et al. 2001) and two distinct polymorphisms of the first two extracellular domains of DBP (Sousa et al. 2006). Our results (unpublished observations) indicate that administration of $P$. vivax proteins in the synthetic adjuvant Montanide ISA 720 (Lawrence et al. 1997) followed by administration of HAd5V vectors expressing equivalent antigens elicit long-term $\mathrm{B}$ and $\mathrm{T}$ cell central as well as effector memory responses, with high levels of IgG1 and IgG2a antibodies. Monkey experiments are currently on their way to define the safety, immunogenicity and protective efficacy of the prime-boost protocol and the $P$. vivax antigens.

Concluding remarks - Adenoviral-vectored vaccines have demonstrated its outstanding value as components of prime-boost protocols for induction of immune responses, in particular polyfunctional cell-mediated (IFN $\gamma /$ IL2/TNF $\alpha$-producing $\mathrm{CD}^{+} \mathrm{T}$ cells) responses, against malaria. In combination with other (mostly viral) platforms, adenoviruses have become an irreplaceable tool to induce immunity against the pre-erythrocytic stages of malaria. Administration of this vaccine platform along with protein-based vaccines may also result in improved levels of Plasmodium-specific antibodies and $\mathrm{CD}^{+} \mathrm{T}$ cells, of extreme interest when fighting the blood-stages of the parasite. Combinations of different viruses (at present the most efficient would be adenoviruses and poxviruses) and/or protein-in-adjuvants in "tailored" immunization protocols, which can be different depending on the pre-erythrocytic or asexual blood-stage antigens used, could end-up solving the immunogenicity problems that malaria vaccine candidates have faced to date. However, still several pre-clinical and clinical trials will have to be performed to define the best adenoviral serotypes and immunization protocols to be used, before firm vaccine candidates may enter industrial pipelines.

\section{REFERENCES}

Adams WC, Gujer C, McInerney G, Gall JG, Petrovas C, Karlsson Hedestam GB, Koup RA, Lore K 2011. Adenovirus type-35 vectors block human $\mathrm{CD} 4{ }^{+}$T-cell activation via CD46 ligation. Proc Natl Acad Sci USA 108: 7499-7504.

Baird JK 2009. Resistance to therapies for infection by Plasmodium vivax. Clin Microbiol Rev 22: 508-534.

Birkett A, Lyons K, Schmidt A, Boyd D, Oliveira GA, Siddique A, Nussenzweig R, Calvo-Calle JM, Nardin E 2002. A modified hepatitis B virus core particle containing multiple epitopes of the Plasmodium falciparum circumsporozoite protein provides a highly immunogenic malaria vaccine in preclinical analyses in rodent and primate hosts. Infect Immun 70: 6860-6870.

Bottcher B, Wynne SA, Crowther RA 1997. Determination of the fold of the core protein of hepatitis B virus by electron cryomicroscopy. Nature 386: 88-91.

Bruder JT, Stefaniak ME, Patterson NB, Chen P, Konovalova S, Limbach K, Campo JJ, Ettyreddy D, Li S, Dubovsky F, Richie 
TL, King CR, Long CA, Doolan DL 2010. Adenovectors induce functional antibodies capable of potent inhibition of blood stage malaria parasite growth. Vaccine 28: 3201-3210.

Bruna-Romero O, Gonzalez-Aseguinolaza G, Hafalla JC, Tsuji M, Nussenzweig RS 2001. Complete, long-lasting protection against malaria of mice primed and boosted with two distinct viral vectors expressing the same plasmodial antigen. Proc Natl Acad Sci USA 98: 11491-11496.

Buchbinder SP, Mehrotra DV, Duerr A, Fitzgerald DW, Mogg R, Li D, Gilbert PB, Lama JR, Marmor M, Del Rio C, McElrath MJ, Casimiro DR, Gottesdiener KM, Chodakewitz JA, Corey L, Robertson MN 2008. Efficacy assessment of a cell-mediated immunity HIV-1 vaccine (the Step Study): a double-blind, randomised, placebo-controlled, test-of-concept trial. Lancet 372: 1881-1893.

Capone S, Reyes-Sandoval A, Naddeo M, Siani L, Ammendola V, Rollier CS, Nicosia A, Colloca S, Cortese R, Folgori A, Hill AV 2010. Immune responses against a liver-stage malaria antigen induced by simian adenoviral vector AdCh63 and MVA prime-boost immunisation in non-human primates. Vaccine 29: 256-265.

Clyde DF 1975. Immunization of man against falciparum and vivax malaria by use of attenuated sporozoites. Am J Trop Med Hyg 24: 397-401.

Clyde DF 1990. Immunity to falciparum and vivax malaria induced by irradiated sporozoites: a review of the University of Maryland studies, 1971-75. Bull World Health Organ 68 (Suppl.): 9-12.

Cunha MG, Rodrigues MM, Soares IS 2001. Comparison of the immunogenic properties of recombinant proteins representing the Plasmodium vivax vaccine candidate MSP1(19) expressed in distinct bacterial vectors. Vaccine 20: 385-396.

DiMenna L, Latimer B, Parzych E, Haut LH, Topfer K, Abdulla S, Yu H, Manson B, Giles-Davis W, Zhou D, Lasaro MO, Ertl HC 2010. Augmentation of primary influenza A virus-specific CD8 ${ }^{+} \mathrm{T}$ cell responses in aged mice through blockade of an immunoinhibitory pathway. J Immunol 184: 5475-5484.

Doolan DL, Martinez-Alier N 2006. Immune response to pre-erythrocytic stages of malaria parasites. Curr Mol Med 6: 169-185.

Douglas AD, de Cassan SC, Dicks MD, Gilbert SC, Hill AV, Draper SJ 2010. Tailoring subunit vaccine immunogenicity: maximizing antibody and $\mathrm{T}$ cell responses by using combinations of adenovirus, poxvirus and protein-adjuvant vaccines against Plasmodium falciparum MSP1. Vaccine 28: 7167-7178.

Draper SJ, Biswas S, Spencer AJ, Remarque EJ, Capone S, Naddeo M, Dicks MDJ, Faber BW, de Cassan SC, Folgori A, Nicosia A, Gilbert SC, Hill AVS 2010. Enhancing blood-stage malaria subunit vaccine immunogenicity in Rhesus macaques by combining adenovirus, poxvirus, and protein-in-adjuvant vaccines. $J$ Immunol 185: 7583-7595.

Ferreira A, Schofield L, Enea V, Schellekens H, van der Meide P, Collins WE, Nussenzweig RS, Nussenzweig V 1986. Inhibition of development of exoerythrocytic forms of malaria parasites by gamma-interferon. Science 232: 881-884.

Fowkes FJ, Richards JS, Simpson JA, Beeson JG 2010. The relationship between anti-merozoite antibodies and incidence of Plasmodium falciparum malaria: a systematic review and meta-analysis. PLoS Med 7: e1000218.

Francis MJ, Hastings GZ, Brown AL, Grace KG, Rowlands DJ, Brown F, Clarke BE 1990. Immunological properties of hepatitis B core antigen fusion proteins. Proc Natl Acad Sci USA 87: 2545-2549.

Goodman AL, Epp C, Moss D, Holder AA, Wilson JM, Gao GP, Long CA, Remarque EJ, Thomas AW, Ammendola V, Colloca S, Dicks MD, Biswas S, Seibel D, van Duivenvoorde LM, Gilbert SC, Hill AV, Draper SJ 2010. New candidate vaccines against blood-stage
Plasmodium falciparum malaria: prime-boost immunization regimens incorporating human and simian adenoviral vectors and poxviral vectors expressing an optimized antigen based on merozoite surface protein 1. Infect Immun 78: 4601-4612.

Harrington LE, Most Rv R, Whitton JL, Ahmed R 2002. Recombinant vaccinia virus-induced T-cell immunity: quantitation of the response to the virus vector and the foreign epitope. J Virol 76: 3329-3337.

Hill AV, Reyes-Sandoval A, O'Hara G, Ewer K, Lawrie A, Goodman A, Nicosia A, Folgori A, Colloca S, Cortese R, Gilbert SC, Draper SJ 2010. Prime-boost vectored malaria vaccines: progress and prospects. Hum Vaccin 6: 78-83.

Hu J, Chen Z, Gu J, Wan M, Shen Q, Kieny MP, He J, Li Z, Zhang Q, Reed ZH, Zhu Y, Li W, Cao Y, Qu L, Cao Z, Wang Q, Liu H, Pan X, Huang X, Zhang D, Xue X, Pan W 2008. Safety and immunogenicity of a malaria vaccine, Plasmodium falciparum AMA-1/MSP-1 chimeric protein formulated in Montanide ISA 720 in healthy adults. PLOS ONE 3: e1952.

John CC, O’Donnell RA, Sumba PO, Moormann AM, de KoningWard TF, King CL, Kazura JW, Crabb BS 2004. Evidence that invasion-inhibitory antibodies specific for the $19-\mathrm{kDa}$ fragment of merozoite surface protein-1 (MSP-1 19) can play a protective role against blood-stage Plasmodium falciparum infection in individuals in a malaria endemic area of Africa. J Immunol 173: 666-672.

Kadekoppala M, Holder AA 2010. Merozoite surface proteins of the malaria parasite: the MSP1 complex and the MSP7 family. Int $J$ Parasitol 40: 1155-1161.

King CL, Michon P, Shakri AR, Marcotty A, Stanisic D, Zimmerman PA, Cole-Tobian JL, Mueller I, Chitnis CE 2008. Naturally acquired Duffy-binding protein-specific binding inhibitory antibodies confer protection from blood-stage Plasmodium vivax infection. Proc Natl Acad Sci USA 105: 8363-8368.

Kochar DK, Saxena V, Singh N, Kochar SK, Kumar SV, Das A 2005. Plasmodium vivax malaria. Emerg Infect Dis 11: 132-134.

Lawrence GW, Saul A, Giddy AJ, Kemp R, Pye D 1997. Phase I trial in humans of an oil-based adjuvant Seppic Montanide ISA 720. Vaccine 15: 176-178.

Li S, Locke E, Bruder J, Clarke D, Doolan DL, Havenga MJ, Hill AV, Liljestrom P, Monath TP, Naim HY, Ockenhouse C, Tang DC, Van Kampen KR, Viret JF, Zavala F, Dubovsky F 2007. Viral vectors for malaria vaccine development. Vaccine 25: 2567-2574.

Li S, Rodrigues M, Rodriguez D, Rodriguez JR, Esteban M, Palese P, Nussenzweig RS, Zavala F 1993. Priming with recombinant influenza virus followed by administration of recombinant vaccinia virus induces $\mathrm{CD} 8^{+} \mathrm{T}$-cell-mediated protective immunity against malaria. Proc Natl Acad Sci USA 90: 5214-5218.

Limbach KJ, Richie TL 2009. Viral vectors in malaria vaccine development. Parasite Immunol 31: 501-519.

Malkin E, Hu J, Li Z, Chen Z, Bi X, Reed Z, Dubovsky F, Liu J, Wang Q, Pan X, Chen T, Giersing B, Xu Y, Kang X, Gu J, Shen Q, Tucker K, Tierney E, Pan W, Long C, Cao Z 2008. A Phase 1 trial of PfCP2.9: an AMA1/MSP1 chimeric recombinant protein vaccine for Plasmodium falciparum malaria. Vaccine 26: 6864-6873.

Malkin E, Long CA, Stowers AW, Zou L, Singh S, MacDonald NJ, Narum DL, Miles AP, Orcutt AC, Muratova O, Moretz SE, Zhou H, Diouf A, Fay M, Tierney E, Leese P, Mahanty S, Miller LH, Saul A, Martin LB 2007. Phase 1 study of two merozoite surface protein 1 (MSP1(42)) vaccines for Plasmodium falciparum malaria. PLoS Clin Trials 2: e12.

McCall MB, Sauerwein RW 2010. Interferon-gamma-central mediator of protective immune responses against the pre-erythrocytic and blood stage of malaria. J Leukoc Biol 88: 1131-1143. 
McGregor IA 1964. The passive transfer of human malarial immunity. Am J Trop Med Hyg 13 (Suppl.): 237-239.

Michon P, Fraser T, Adams JH 2000. Naturally acquired and vaccineelicited antibodies block erythrocyte cytoadherence of the Plasmodium vivax Duffy binding protein. Infect Immun 68: 3164-3171.

Miller LHMS, Clyde DF, McGinnis MH 1976. The resistance factor to Plasmodium vivax in blacks: Duffy blood group genotype, FyFy. $N$ Engl J Med 295: 302-304.

Mita T, Tanabe K, Kita K 2009. Spread and evolution of Plasmodium falciparum drug resistance. Parasitol Int 58: 201-209.

Moorthy VS, Pinder M, Reece WH, Watkins K, Atabani S, Hannan C, Bojang K, McAdam KP, Schneider J, Gilbert S, Hill AV 2003. Safety and immunogenicity of DNA/modified vaccinia virus ankara malaria vaccination in African adults. J Infect Dis 188: 1239-1244.

Murphy KM, Nelson CA, Sedy JR 2006. Balancing co-stimulation and inhibition with BTLA and HVEM. Nat Rev Immunol 6: 671-681.

Nanda N, Yadav RS, Subbarao SK, Joshi H, Sharma VP 2000. Studies on Anopheles fluviatilis and Anopheles culicifacies in relation with malaria in forest and deforested riverine ecosystems in northern Orissa, India. J Am Mosq Contr Assoc 16: 199-205.

Nussenzweig RS, Vanderberg J, Most H, Orton C 1967. Protective immunity produced by the injection of $\mathrm{x}$-irradiated sporozoites of Plasmodium berghei. Nature 216: 160-162.

Ogutu BR, Apollo OJ, McKinney D, Okoth W, Siangla J, Dubovsky F, Tucker K, Waitumbi JN, Diggs C, Wittes J, Malkin E, Leach A, Soisson LA, Milman JB, Otieno L, Holland CA, Polhemus M, Remich SA, Ockenhouse CF, Cohen J, Ballou WR, Martin SK, Angov E, Stewart VA, Lyon JA, Heppner DG, Withers MR 2009. Blood stage malaria vaccine eliciting high antigen-specific antibody concentrations confers no protection to young children in western Kenya. PLoS ONE 4: e4708.

Olotu A, Lusingu J, Leach A, Lievens M, Vekemans J, Msham S, Lang T, Gould J, Dubois MC, Jongert E, Vansadia P, Carter T, Njuguna P, Awuondo KO, Malabeja A, Abdul O, Gesase S, Mturi N, Drakeley CJ, Savarese B, Villafana T, Lapierre D, Ballou WR, Cohen J, Lemnge MM, Peshu N, Marsh K, Riley EM, von Seidlein L, Bejon P 2011. Efficacy of RTS,S/AS01E malaria vaccine and exploratory analysis on anti-circumsporozoite antibody titres and protection in children aged 5-17 months in Kenya and Tanzania: a randomised controlled trial. Lancet Infect Dis 11: 102-109.

Ophorst OJ, Kostense S, Goudsmit J, De Swart RL, Verhaagh S, Zakhartchouk A, Van Meijer M, Sprangers M, Van Amerongen G, Yuksel S, Osterhaus AD, Havenga MJ 2004. An adenoviral type 5 vector carrying a type 35 fiber as a vaccine vehicle: DC targeting, cross neutralization, and immunogenicity. Vaccine 22: 3035-3044.

Ophorst OJ, Radosevic K, Havenga MJ, Pau MG, Holterman L, Berkhout B, Goudsmit J, Tsuji M 2006. Immunogenicity and protection of a recombinant human adenovirus serotype 35-based malaria vaccine against Plasmodium yoelii in mice. Infect Immun 74: 313-320.

Palma C, Overstreet MG, Guedon JM, Hoiczyk E, Ward C, Karen KA, Zavala F, Ketner G 2011. Adenovirus particles that display the Plasmodium falciparum circumsporozoite protein NANP repeat induce sporozoite-neutralizing antibodies in mice. Vaccine 29: 1683-1689.

Peiperl L, Morgan C, Moodie Z, Li H, Russell N, Graham BS, Tomaras GD, De Rosa SC, McElrath MJ 2010. Safety and immunogenicity of a replication-defective adenovirus type 5 HIV vaccine in Ad5seronegative persons: a randomized clinical trial (HVTN 054). PLOS ONE 5: e13579.

Pichla-Gollon SL, Lin SW, Hensley SE, Lasaro MO, Herkenhoff-Haut L, Drinker M, Tatsis N, Gao GP, Wilson JM, Ertl HC, Bergelson JM 2009. Effect of preexisting immunity on an adenovirus vac- cine vector: in vitro neutralization assays fail to predict inhibition by antiviral antibody in vivo. J Virol 83: 5567-5573.

Pierce MA, Ellis RD, Martin LB, Malkin E, Tierney E, Miura K, Fay MP, Marjason J, Elliott SL, Mullen GE, Rausch K, Zhu D, Long CA, Miller LH 2010. Phase 1 safety and immunogenicity trial of the Plasmodium falciparum blood-stage malaria vaccine AMA1C1/ISA 720 in Australian adults. Vaccine 28: 2236-2242.

Radosevic K, Rodriguez A, Lemckert AA, van der Meer M, Gillissen G, Warnar C, von Eyben R, Pau MG, Goudsmit J 2010. The Th1 immune response to Plasmodium falciparum circumsporozoite protein is boosted by adenovirus vectors 35 and 26 with a homologous insert. Clin Vaccine Immunol 17: 1687-1694.

Reyes-Sandoval A, Berthoud T, Alder N, Siani L, Gilbert SC, Nicosia A, Colloca S, Cortese R, Hill AV 2010. Prime-boost immunization with adenoviral and modified vaccinia virus Ankara vectors enhances the durability and polyfunctionality of protective malaria CD8 ${ }^{+}$T-cell responses. Infect Immun 78: 145-153.

Roberts DM, Nanda A, Havenga MJ, Abbink P, Lynch DM, Ewald BA, Liu J, Thorner AR, Swanson PE, Gorgone DA, Lifton MA, Lemckert AA, Holterman L, Chen B, Dilraj A, Carville A, Mansfield KG, Goudsmit J, Barouch DH 2006. Hexon-chimaeric adenovirus serotype 5 vectors circumvent pre-existing anti-vector immunity. Nature 441: 239-243.

Rocha CD, Caetano BC, Machado AV, Bruna-Romero O 2004. Recombinant viruses as tools to induce protective cellular immunity against infectious diseases. Int Microbiol 7: 83-94.

Rodrigues EG, Zavala F, Eichinger D, Wilson JM, Tsuji M 1997. Single immunizing dose of recombinant adenovirus efficiently induces $\mathrm{CD} 8^{+} \mathrm{T}$ cell-mediated protective immunity against malaria. J Immunol 158: 1268-1274.

Rodrigues MH, Rodrigues KM, Oliveira TR, Comodo AN, Rodrigues MM, Kocken CH, Thomas AW, Soares IS 2005. Antibody response of naturally infected individuals to recombinant Plasmodium vivax apical membrane antigen-1. Int J Parasitol 35: 185-192.

Rodriguez A, Mintardjo R, Tax D, Gillissen G, Custers J, Pau MG, Klap J, Santra S, Balachandran H, Letvin NL, Goudsmit J, Radosevic K 2009. Evaluation of a prime-boost vaccine schedule with distinct adenovirus vectors against malaria in Rhesus monkeys. Vaccine 27: 6226-6233.

Roestenberg M, Remarque E, de Jonge E, Hermsen R, Blythman H, Leroy O, Imoukhuede E, Jepsen S, Ofori-Anyinam O, Faber B, Kocken CH, Arnold M, Walraven V, Teelen K, Roeffen W, de Mast Q, Ballou WR, Cohen J, Dubois MC, Ascarateil S, van der Ven A, Thomas A, Sauerwein R 2008. Safety and immunogenicity of a recombinant Plasmodium falciparum AMA1 malaria vaccine adjuvanted with Alhydrogel, Montanide ISA 720 or AS02. PLOS ONE 3: e3960.

Saul A, Lawrence G, Allworth A, Elliott S, Anderson K, Rzepczyk C, Martin LB, Taylor D, Eisen DP, Irving DO, Pye D, Crewther PE, Hodder AN, Murphy VJ, Anders RF 2005. A human Phase 1 vaccine clinical trial of the Plasmodium falciparum malaria vaccine candidate apical membrane antigen 1 in Montanide ISA 720 adjuvant. Vaccine 23: 3076-3083.

Schofield L, Villaquiran J, Ferreira A, Schellekens H, Nussenzweig $\mathrm{R}$, Nussenzweig V 1987. Gamma interferon, $\mathrm{CD}^{+} \mathrm{T}$ cells and antibodies required for immunity to malaria sporozoites. $\mathrm{Na}$ ture 330: 664-666.

Schwenk RJ, Richie TL 2011. Protective immunity to pre-erythrocytic stage malaria. Trends Parasitol 27: 306-314.

Shiratsuchi T, Rai U, Krause A, Worgall S, Tsuji M 2010. Replacing adenoviral vector HVR1 with a malaria B cell epitope improves immunogenicity and circumvents preexisting immunity to adenovirus in mice. J Clin Invest 120: 3688-3701. 
Shott JP, McGrath SM, Pau MG, Custers JH, Ophorst O, Demoitie MA, Dubois MC, Komisar J, Cobb M, Kester KE, Dubois P, Cohen J, Goudsmit J, Heppner DG, Stewart VA 2008. Adenovirus 5 and 35 vectors expressing Plasmodium falciparum circumsporozoite surface protein elicit potent antigen-specific cellular IFNgamma and antibody responses in mice. Vaccine 26: 2818-2823.

Silvie O, Franetich JF, Charrin S, Mueller MS, Siau A, Bodescot M, Rubinstein E, Hannoun L, Charoenvit Y, Kocken CH, Thomas AW, Van Gemert GJ, Sauerwein RW, Blackman MJ, Anders RF, Pluschke G, Mazier D 2004. A role for apical membrane antigen 1 during invasion of hepatocytes by Plasmodium falciparum sporozoites. J Biol Chem 279: 9490-9496.

Sousa TN, Ceravolo IP, Fernandes Fontes CJ, Couto A, Carvalho LH, Brito CF 2006. The pattern of major polymorphisms in the Duffy binding protein ligand domain among Plasmodium vivax isolates from the Brazilian Amazon area. Mol Biochem Parasitol 146: 251-254.

Stanisic DI, Richards JS, McCallum FJ, Michon P, King CL, Schoepflin S, Gilson PR, Murphy VJ, Anders RF, Mueller I, Beeson JG 2009. Immunoglobulin G subclass-specific responses against Plasmodium falciparum merozoite antigens are associated with control of parasitemia and protection from symptomatic illness. Infect Immun 77: 1165-1174.

Stewart VA, McGrath SM, Dubois PM, Pau MG, Mettens P, Shott J, Cobb M, Burge JR, Larson D, Ware LA, Demoitie MA, Weverling GJ, Bayat B, Custers JH, Dubois MC, Cohen J, Goudsmit J,
Heppner DG, Jr. 2007. Priming with an adenovirus 35-circumsporozoite protein (CS) vaccine followed by RTS,S/AS01B boosting significantly improves immunogenicity to Plasmodium falciparum CS compared to that with either malaria vaccine alone. Infect Immun 75: 2283-2290.

Tatsis N, Fitzgerald JC, Reyes-Sandoval A, Harris-McCoy KC, Hensley SE, Zhou D, Lin SW, Bian A, Xiang ZQ, Iparraguirre A, Lopez-Camacho C, Wherry EJ, Ertl HC 2007. Adenoviral vectors persist in vivo and maintain activated $\mathrm{CD} 8^{+} \mathrm{T}$ cells: implications for their use as vaccines. Blood 110: 1916-1923.

Tjitra E, Anstey NM, Sugiarto P, Warikar N, Kenangalem E, Karyana M, Lampah DA, Price RN 2008. Multidrug-resistant Plasmodium vivax associated with severe and fatal malaria: a prospective study in Papua, Indonesia. PLoS Med 5: e128.

Triglia T, Healer J, Caruana SR, Hodder AN, Anders RF, Crabb BS, Cowman AF 2000. Apical membrane antigen 1 plays a central role in erythrocyte invasion by Plasmodium species. $\mathrm{Mol}$ Microbiol 38: 706-718.

Vogels R, Zuijdgeest D, van Rijnsoever R, Hartkoorn E, Damen I, de Bethune MP, Kostense S, Penders G, Helmus N, Koudstaal W, Cecchini M, Wetterwald A, Sprangers M, Lemckert A, Ophorst O, Koel B, van Meerendonk M, Quax P, Panitti L, Grimbergen J, Bout A, Goudsmit J, Havenga M 2003. Replication-deficient human adenovirus type 35 vectors for gene transfer and vaccination: efficient human cell infection and bypass of preexisting adenovirus immunity. J Virol 77: 8263-8271. 